\title{
Use of Rapid Antibody Test in 3 patients with suspected Coronovirus Disease-19 (COVID-19) with 2 time Polymerase Chain Reaction (PCR) test negative: A case report
}

\section{Kez Polymerase Chain Reaction (PCR) Testi negatif sonuçlanan Coronovirus Disease-19 (COVID-19) şüpheli 3 hastada hızlı antikor testinin kullanımı: Olgu sunumu}

Cihan Yeșili ${ }^{1}$, Burak Okyar ${ }^{2}$

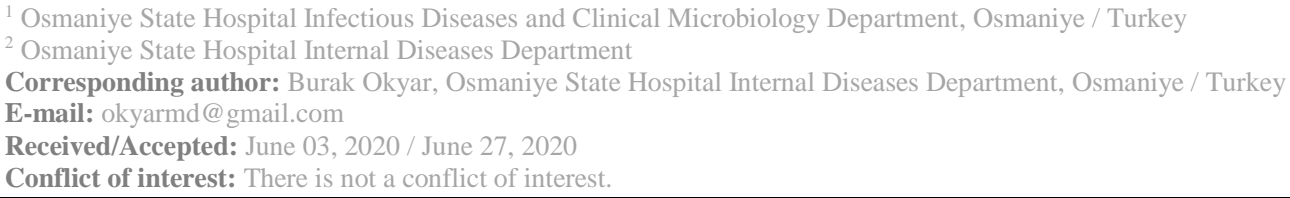

\section{SUMMARY}

Tests used to diagnose Coronavirus Disease-2019 (COVID-19) disease; Polymerase Chain Reaction (PCR) test, Rapid Antibody Test (RAT) and Thorax Computed Tomography (CT) in patients with appropriate history, clinical and laboratory. The sensitivity of these tests changes during the course of the disease and it is difficult to diagnose if the appropriate test is not selected at the appropriate time.

PCR test was applied to 3 cases who applied to our hospital and had findings suggesting COVID-19 in CT, and all tests were negative. Afterwards, 3 cases diagnosed with RAT and COVID-19 were treated appropriately.

These 3 cases showed that PCR test negativity is not an adequate criterion to rule out the disease. Even if the PCR test is negative in patients with appropriate history and clinic, RAT and / or CT should be performed considering the time elapsed since the onset of the patient's symptoms.

Keywords: COVID-19, Polymerase Chain Reaction, rapid antibody test

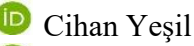

(iD) Burak Okyar

ORCID IDs of the authors: C.Y. 0000-0003-3558-5689 B.O. 0000-0002-9028-9930

\section{ÖZET}

Coronavirus Disease-2019 (COVİD-19) hastalığının tanısını koymak için kullanılan testler; uygun öykü, klinik ve laboratuvara sahip hastalarda Polymerase Chain Reaction (PCR) testi, Hizlı Antikor Testi (HAT) ve Toraks Bilgisayarl1 Tomografi (BT)'den oluşmaktadır. Bu testlerin duyarlılıkları, hastalığın seyri sırasında değişmekte ve uygun zamanda uygun test seçilmediği taktirde tanının konulması zorlaşmaktadır.

Hastanemize başvuran ve BT'de COVİD-19 düşündüren bulgulara sahip olan 3 vakamıza PCR testi uygulanmış olup, tüm testler negatif gelmiştir. Daha sonrasında yapılan HAT ile COVID-19 tanısı kesinleştirilen 3 vaka uygun şekilde tedavi edilmiștir.

Bu 3 vaka göstermiştir ki PCR testi negatifliği hastalığı dışlamak için yeterli bir kriter değildir. Uygun öykü ve kliniği olan hastalarda PCR testi negatif dahi olsa, hastanın semptomlarının başlangıcından itibaren geçen süre dikkate alınarak HAT ve/veya BT uygulanmalidir.

Anahtar sözcükler: COVID-19, Polymerase Chain Reaction, hizlı antikor testi 


\section{INTRODUCTION}

Polymerase Chain Reaction (PCR) test is the basic test used to diagnose Coronavirus Disease-2019 (COVID-19) disease caused by the SARS-CoV-2 virus. Another method used to diagnose this disease is rapid antibody testing (RAT) ${ }^{1}$. Computed Tomography (CT), on the other hand, has been shown to be a highly sensitive imaging method in the diagnosis of COVID-19 and can be used to determine the prognosis of the disease ${ }^{2,3}$. Many factors affect the sensitivity and specificity of PCR tests, such as taking, storing and sending the sample, the duration of the test, and the time of patient admission to the hospital. In a 139-case study conducted by Kazuo Imai et al. In Japan, serum COVID-19-specific immunoglobulin-M (IgM) test was found positive in $27.8 \%$ of patients at the first week of onset of symptoms. Between the first and second week, $48 \%$ of patients were positive. After the second week, the patients were found to be $95.8 \%$ positive. In the same study, the combined use of antibody test and thorax CT in asymptomatic patients was found to be significantly higher in diagnosis than only antibody test use and it was stated that these two tests should be used in combination when the PCR test cannot be applied ${ }^{1}$. In the study conducted by Juanjuan Zhao et al. In 173 patients; From the beginning of the symptoms of patients diagnosed with COVID19 , a decrease in the viral load of the patients and an increase in the inflammatory response were detected at the end of the first week. With the reduction of viral load, the probability of diagnosis with PCR has been significantly reduced. According to the results of patients diagnosed with COVID-19 in the same study; In the first week from the onset of symptoms, $63 \%$ of patients were diagnosed with the PCR test. Between the first and second week, $54 \%$ of patients were diagnosed. After the second week, $45 \%$ of patients were diagnosed ${ }^{4}$. With the IgM antibody examined in this study; In the first week, $29 \%$ of patients were diagnosed. Between the first and second week, $73 \%$ of patients were diagnosed. After the second week, $94 \%$ of patients were diagnosed. These results show that the PCR test in the early period of the disease and the antibody test in the late period are higher than the accuracy rates. It is understood from these studies that PCR test will give more accurate results in terms of COVID-19 screening in asymptomatic individuals, and in cases where PCR test cannot be applied, it has been shown that the combined use of antibody testing and imaging will give more accurate results ${ }^{1}$.

At Osmaniye State Hospital (OSH), we performed two PCR tests twice in a 24-hour period, meeting 3 possible patients who met the possible case criteria, were symptomatic and supported the diagnosis of CT findings COVID-19. Both tests resulted negatively. We then applied RAT to these 3 patients who had extensive bilateral lung involvement in their CT. We have confirmed COVID-19 positive diagnoses for the treatment of RAT positive patients.

\section{CASE 1}

A 72-year-old male patient was admitted to the district state hospital with a cough and a beginning dyspnea on the 9th day from the onset of symptoms. There was no history of fever. There was close contact with the confirmed case of COVID-19 in his history. Pulse oximeter oxygen saturation measured by finger was $88 \%$. The pulse was 98 / minute (min) and the respiratory rate (SS) was $28 / \mathrm{min}$. Measurement from fever was 37.1 degrees, blood pressure arterial (BPA) was 90/60 $\mathrm{mmHg}$. Routine laboratory test results as follows; White Blood Cell (WBC): $5.6310^{3} / \mu 1$, Hemoglobulin (HGB): $13.1 \mathrm{~g} / \mathrm{dL}$, Lymphocyte (LYM): $0.8110^{\wedge} / \mathrm{L}$, Neutrophil (NEUT): 4.2510 $\wedge$ / L, Platelet (PLT) ): $24810^{3} / \mu$ l, D-Dimer: 7.2 $\mu \mathrm{g} / \mathrm{mL}, \mathrm{C}$-reactive Protein (CRP): $143.5 \mathrm{mg} / \mathrm{L}$, Creatinine (CRE): $0.9 \mathrm{mg} / \mathrm{dL}$, Aspartate Aminotransferase (AST): $21 \mathrm{U} / \mathrm{L}$, Alanine Aminotransferase (ALT): $14.8 \mathrm{U} / \mathrm{L}$, Lactate Dehydrogenase (LDH): 315 U / L, International Normalized Ratio (INR): 1.15, Troponin T (TropT): $11.64 \mathrm{pg} / \mathrm{mL}$. Bilateral ground-glass areas and widespread consolidation were seen in the non-contrast CT imaging (Image-1). When the patient needed intensive care, our hospital was taken to intensive care. Nasopharyngeal sample was taken from the patient using oropharyngeal and then the same swab. The PCR test was performed with the sample taken, following the appropriate storage and transfer rules, and a second PCR test was performed 24 hours later with the same method. After the patient's result was negative again, RAT was applied to our patient and treatment of the patient who received positive IgM RAT was continued with the diagnosis of COVID19 positive. 


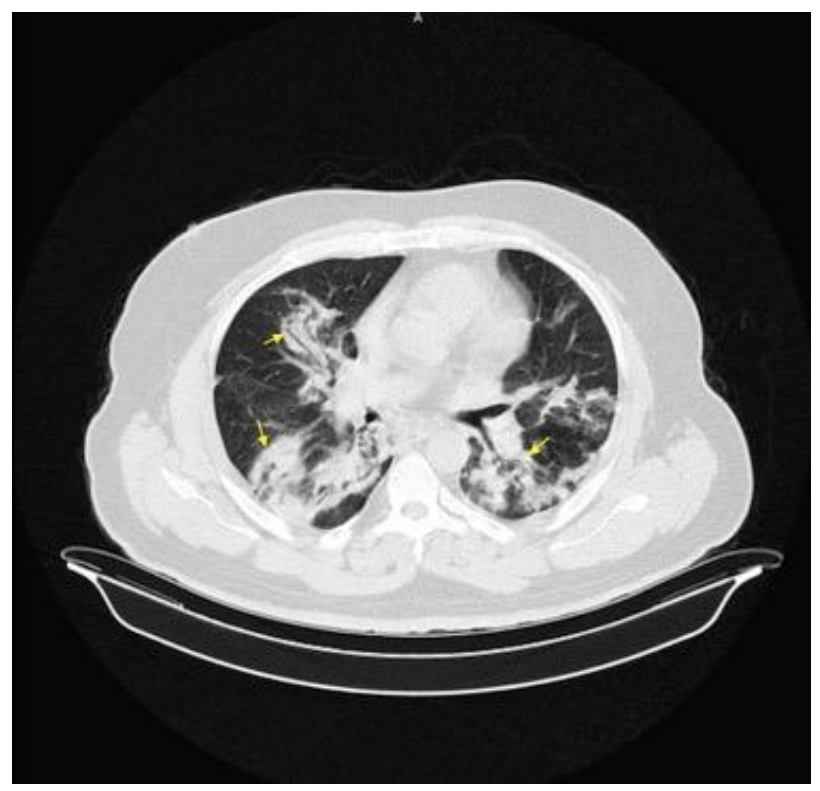

Image 1: Bilateral ground-glass areas and extensive consolidation

\section{CASE 2}

A 60-year-old male patient applied to OSH with the complaint of shortness of breath and cough on the 10th day from the onset of symptoms. There was close contact with the confirmed case of COVID19 in his history. There was no history of fever. Pulse oximeter oxygen saturation measured from the finger was $95 \%$. The pulse was $92 / \mathrm{min}, \mathrm{SS} 12$ / min, fever 36.2 degrees, BPA 120/80 mmHg. Routine laboratory test results as follows; WBC: $4.6610^{3} / \mu 1$, HGB: $16.1 \mathrm{~g} / \mathrm{dL}, \mathrm{LYM}: 1.2510^{\wedge} /$ L, NEUT: $2.7110^{\wedge} / \mathrm{L}$, PLT: $15010^{3} / \mu \mathrm{l}$, DDimer: $0.1 \mu \mathrm{g} / \mathrm{mL}, \mathrm{CRP}: 12.7 \mathrm{mg}$ / L, CRE: 0.8 mg / dL, AST: 22.4 U / L, ALT: 20.3 U / L, LDH 220 U / L, INR: 1, TropT: $<0.3$ pg / mL. In noncontrast CT imaging (Image-2), the ground glass areas, as well as consolidation areas and interseptal thickening were observed. The patient was admitted to our hospital, before the oropharyngeal, and then the nasopharyngeal sample was taken using the same swab. The PCR test was performed with the sample taken, following the appropriate storage and transfer conditions, and a second PCR test was performed 24 hours later with the same method. After the patient's result was negative again, RAT was applied to our patient, IgM resulted as RAT positive and treatment was continued with the diagnosis of COVID-19 positive.

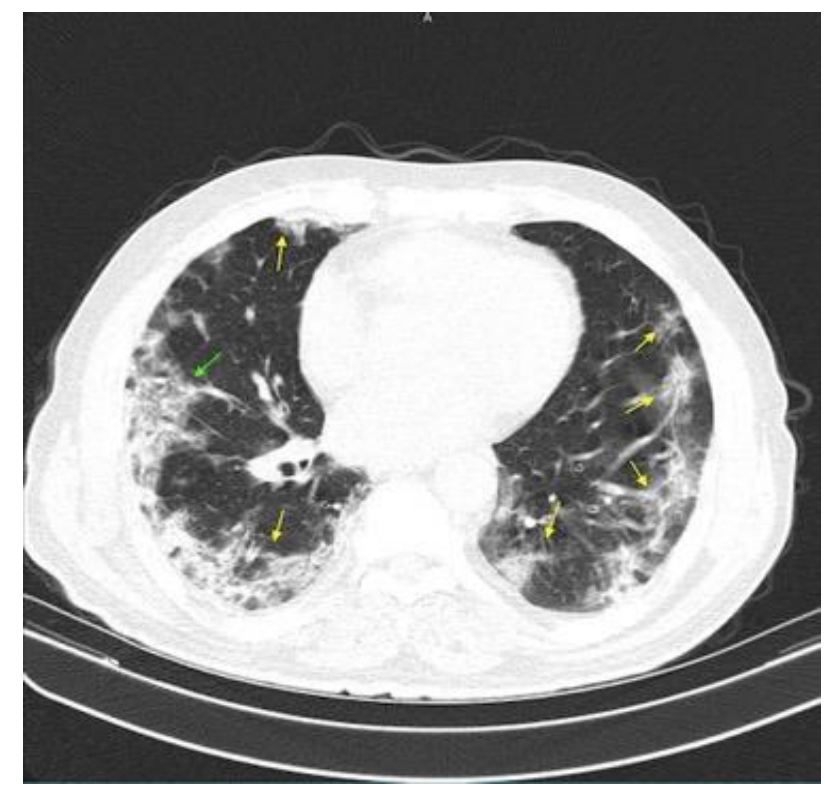

Image 2: Ground glass areas, consolidation areas and interseptal thickening

\section{CASE 3}

A 52-year-old male presented to OSH with dyspnea and cough on the 8th day from the onset of symptoms. There was close contact with the confirmed case of COVID-19 in his history. There was no history of fever. Pulse oximeter oxygen saturation measured by finger was $65 \%$. The pulse was 88 / min, SS 24 / min, fever 37.1 degrees, BPA $110 / 90 \mathrm{mmHg}$. Routine laboratory test results as follows; WBC: $10.7310^{3} / \mu 1$, HGB: $13.5 \mathrm{~g} / \mathrm{dL}$, LYM: $1.0010^{\wedge} / \mathrm{L}$, NEUT: $8.2310^{\wedge} / \mathrm{L}$, PLT: $21410^{3} / \mu$, D-Dimer: $0.9 \mu \mathrm{g} / \mathrm{mL}, \mathrm{CRP}: 71.5 \mathrm{mg}$ / L, CRE: $0.9 \mathrm{mg} / \mathrm{dL}$, AST: $82.5 \mathrm{U} / \mathrm{L}, \mathrm{ALT}: 143.6$ U / L, LDH 539 U / L, INR: 1.13, TropT: 5.83 pg / $\mathrm{mL}$. Widespread ground-glass areas were present in the patient non-contrast CT imaging (Image-3). It was taken from the district state hospital and hospitalized in the intensive care of our hospital. Nasopharyngeal sample was taken from the patient using oropharyngeal and then the same swab. The PCR test was performed with the sample taken, following the appropriate storage and transfer conditions, and a second PCR test was performed 24 hours later with the same method. After the patient's result was negative again, RAT was applied to our patient. IgM RAT resulted positively and treatment was continued with a diagnosis of COVID-19 positive. 


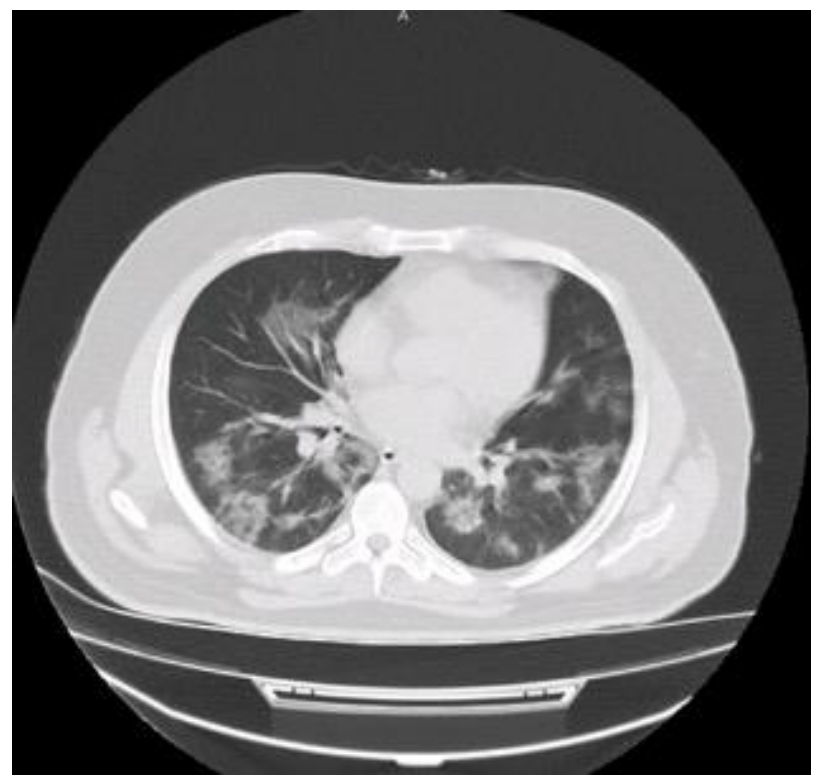

Image 3: Diffuse ground-glass areas

\section{DISCUSSION}

COVID-19 disease can be encountered with a wide range of clinical features from asymptomatic course to Acute Respiratory Distress Syndrome (ARDS); It is a viral disease with a high human to human transmission rate that may cause patients to apply to the hospital with nonspecific complaints such as cough, shortness of breath, fever, headache and sore throat, myalgia, diarrhea. In addition to clinical findings, many laboratory tests are used to predict the prognosis of the disease, and CT findings give an idea ${ }^{5}$. Sometimes patients can apply to health centers with only one symptom without all of these symptoms. Sudden loss of taste and smell, widespread myalgia and conjunctivitis are also rare symptoms ${ }^{6}$. Various tests are used to diagnose COVID-19 disease in these patients. The most common among these are PCR, HAT, and CT as the imaging method. The presence of groundglass areas and / or consolidation, especially in bilateral lower zones and periphery, are common CT findings for COVID-19 7,8. In the study conducted by Juanjuan Zhao et al., It has been observed that the sensitivity of PCR in diagnosis has decreased and the probability of RAT test becoming positive has increased since the first day of patients' symptoms. They determined that the rate of diagnosis of PCR decreased up to 54\% especially after 8 th day in symptomatic patients, and they found that the probability of diagnosis (especially IgM positivity) of RAT after 8th day increased to $73 \%$ in the symptomatic patients ${ }^{4}$.

In our patients, the first PCR test was performed approximately 9 days after the onset of symptoms. The results of 2 tests performed 24 hours apart were also negative. The RAT test performed on the average 11th day from the onset of symptoms resulted positively in all three patients. These 3 cases support that the sensitivity of PCR decreases over time and the sensitivity of RAT increases in patients presenting with the diagnosis of COVID19. Studies and three cases diagnosed by us show that; RAT and imaging rather than PCR testing will reduce our chances of skipping cases in patients with appropriate history and their symptoms over a period of time. It has been shown in studies that COVID-19 disease is transmitted mostly through droplet path and contact ${ }^{9}$. For this reason, separating the people with the disease from healthy people and treating them with isolation is the most important step in the struggle with COVID-19. At the same time, it will strengthen our hand in determining the treatment options and regulating the duration of treatment by finalizing the diagnosis. When used at the right time and with the appropriate indication, RAT can be used as a highly sensitive test in diagnosis. In addition, these results showed that in possible cases with PCR test negative and compatible CT findings, the use of RAT is effective in making the correct diagnosis after a certain period of time since the symptoms have appeared.

\section{CONCLUSION}

In cases suggesting COVID-19 disease by clinical, laboratory and / or imaging, confirming the diagnosis and taking appropriate measures are the most important step in combating this disease. PCR, RAT and CT usage must be customized for the patient in the diagnosis of COVID-19. It is very important to determine which diagnostic test and when to use to make the correct diagnosis to the patients, and to use the correct diagnostic test to minimize the possibility of missing a case. In this way, as the resources are used correctly, the diagnosis will be made with the highest probability.

\section{ACKNOWLEDGMENT}

There is no conflict of interest among the authors. No financial support was received in this case report. Informed consent was obtained from the patients. The data were obtained retrospectively.

\section{REFERENCES}

1. Imai $K$, Tabata $S$, Ikeda $M$, et al. Clinical evaluation of an immunochromatographic $\mathrm{IgM} / \mathrm{IgG}$ antibody assay and chest computed tomography for the diagnosis of COVID-19 J Clin Virol. 2020 Jul; 128: 104393. Published online $2020 \quad$ Apr 30. doi: $10.1016 /$ j.jcv.2020.104393 
2. Bai HX, Hsieh B, Xiong Z, et al. Performance of radiologists in di erentiating COVID-19 from viral pneumonia on chest CT, Radiology (2020), https://doi.org/10.1148/radiol.2020200823.

3. Huang P, Liu T, Huang L, et al. Use of chest CT in com- bination with negative RT-PCR assay for the 2019 novel coronavirus but high clinical suspicion, Radiology https://doi.org/10.1148/radiol. 2020200330:200330.

4. Zhao J, Yuan Q, Wang H, et al. Antibody responses to SARS-COV-2 in patients of novel coronavirus disease $2019 . \quad$ DOI: 10.1093/cid/ciaa344.

5. Guan W, Ni Z, $\mathrm{Hu}$ Y, et al.Clinical characteristics of 2019 novel coronavirus infection in China. $\mathrm{N}$ Engl $\mathrm{J}$ Med. DOI: 10.1056/NEJMoa2002032
6. Wang M, Wu Q, Xu W, et al. Clinical Diagnosis of 8274 samples with 2019-novel coronavirus in Wuhan. medRxiv 2020; published online Feb 18. DOI:10.1101/2020.02.12.20022327.

7. Revel MP, Parkar AP, Prosch H, et al. European Society of Radiology (ESR) and the European Society of Thoracic Imaging (ESTI). Eur Radiol. 2020 Apr 20. doi: 10.1007/s00330-02006865-y.

8. Spiezia L, Boscolo A, Poletto F, et al. COVID19-Related Severe Hypercoagulability in Patients Admitted to Intensive Care Unit for Acute Respiratory Failure 2020 . doi: 10.1055/s-0040-1710018.

9. Huang C, Wang Y, Li X, et al. Clinical features of patients infected with 2019 novel coronavirus in Wuhan, China, Lancet 395; 2020 497-506. 